\title{
Motivational Effects of Ethanol in DARPP-32 Knock-Out Mice
}

\author{
Fred O. Risinger, ${ }^{1}$ Pierre A. Freeman, ${ }^{1}$ Paul Greengard, ${ }^{2}$ and Allen A. Fienberg ${ }^{2,3}$ \\ ${ }^{1}$ Department of Behavioral Neuroscience, Oregon Health Sciences University, Portland, Oregon 97201-3098, \\ 2 Laboratory of Molecular and Cellular Neuroscience, The Rockefeller University, New York, New York 10021, and \\ ${ }^{3}$ Genomics Institute of the Novartis Research Foundation, San Diego, California 92121
}

DARPP-32 (dopamine and adenosine 3',5'-monophosphateregulated phosphoprotein, $32 \mathrm{kDa}$ ) is an important component of dopaminergic function in brain areas thought to be important for drug and alcohol addiction. The present experiments characterized the acquisition of ethanol-induced conditioned taste aversion, ethanol-induced conditioned place preference, and ethanol self-administration in DARPP-32 knock-out (KO) mice compared to wild-type (WT) controls. For taste conditioning, $\mathrm{KO}$ and WT mice received access to $0.2 \mathrm{M} \mathrm{NaCl}$ solution followed immediately by intraperitoneal injection of $0-4 \mathrm{gm} / \mathrm{kg}$ ethanol. Ethanol produced dose-dependent conditioned taste aversion that was the same in both genotypes. For place conditioning, $\mathrm{KO}$ and WT mice received eight pairings of a tactile stimulus with ethanol (2 gm/ $\mathrm{kg}$, i.p.), and a different stimulus with saline. Ethanol produced increases in locomotor activity during conditioning, with $\mathrm{KO}$ mice showing higher activity levels after ethanol compared to WT mice. WT mice, but not $\mathrm{KO}$ mice, acquired conditioned preference for the ethanolpaired stimulus. In the self-administration procedure, KO and WT mice were trained to lever press for access to $10 \% \mathrm{v} / \mathrm{v}$ ethanol. Subsequently, the mice had $23 \mathrm{hr} / \mathrm{d}$ access to food, ethanol, and water. Response patterns were determined using 0-30\% v/v ethanol concentrations. WT mice displayed concentrationdependent responding for ethanol. Responding on the ethanol lever by $\mathrm{KO}$ mice did not change as a function of ethanol concentration. Saccharin $(0.2 \% \mathrm{w} / \mathrm{v})$ was subsequently added to the ethanol mixture, and responding was examined at 0, 5, 10, and $20 \%$ ethanol concentrations. Ethanol responding increased in both genotypes, although WT mice showed higher rates at all concentrations.

Key words: ethanol; conditioned taste aversion; conditioned place preference; self-administration; reward; reinforcement; DARPP-32 knock-out mice
Contemporary views of addiction emphasize behaviors related to the experience of hedonic consequences after drug exposure (Wise, 1998). For example, individual differences in sensitivity to the rewarding or aversive effects of ethanol are thought to contribute to the development of excessive drinking (Tabakoff and Hoffman, 1988). Although several neurotransmitter systems contribute to ethanol reward (Koob et al., 1998), dopaminergic mechanisms have achieved the most prominence in neural circuitry models of the positive motivational effects of abused drugs including ethanol (Koob, 1999). A dopaminergic pathway important for drug reward appears to be mesocorticolimbic brain areas, which include the ventral tegmental area, nucleus accumbens, olfactory tubercle, amygdala, frontal cortex, and septal area (Koob, 1992). Currently, dopamine receptor subtypes are classified as D1-like (D1 and D5 receptors) and D2-like (D2, D3, and D4 receptors) (Civelli et al., 1993). Both D1-like and D2-like receptors are found in reward-related brain areas (Civelli et al., 1993).

An important molecular mechanism for the effects of dopamine acting through D1- and D2-like receptors is protein phosphorylation (Greengard et al., 1998). One phosphoprotein, DARPP-32 (dopamine and adenosine 3',5'-monophosphate-

Received Aug. 11, 2000; revised Oct. 16, 2000; accepted Oct. 19, 2000.

This work was supported by National Institutes of Health Grants AA10760, AA10520, DA10044, and MH40899. Thanks to Angela Doan and Ma Vang for assistance with data collection.

Correspondence should be addressed to Dr. Fred O. Risinger, Department of Behavioral Neuroscience, L470, Oregon Health Sciences University, 3181 SW Sam Jackson Park Road, Portland, OR 97201-3098. E-mail: risinger@ohsu.edu. Copyright (C) 2001 Society for Neuroscience $0270-6474 / 01 / 210340-09 \$ 15.00 / 0$ regulated phosphoprotein, $32 \mathrm{kDa}$ ), appears particularly important for regulation of striatal dopaminergic systems (Greengard et al., 1999). To date, specific pharmacological antagonists for DARPP-32 are unavailable. However, mice with targeted disruption of the DARPP-32 gene have been recently developed, enabling investigations into the role of this protein in mediating the actions of dopamine as well as drugs of abuse (Fienberg et al., 1998; Fienberg and Greengard, 2000). DARPP-32 null mutants, which lack detectable DARPP-32 protein in the brain, appear developmentally normal but show diminished sensitivity to dopamine in electrophysiological and biochemical preparations (Fienberg and Greengard, 2000). DARPP-32 knock-out (KO) mice have normal levels of dopamine D1 and D2 receptors, but reduced immediate early gene expression after treatment with a D1 receptor agonist SKF 82958 (Svenningsson et al., 2000). In addition, acute cocaine-stimulated activity is reduced in DARPP-32 KO mice, as is raclopride-induced catalepsy (Fienberg et al., 1998).

The experiments reported here were devoted to characterizing sensitivity to ethanol's motivational effects in DARPP-32 KO mice, using several different procedures including taste conditioning, place conditioning, and ethanol self-administration. Each of these procedures has been associated with indexing the motivational effects of ethanol. Most self-administered drugs produce conditioned taste aversion, and this response has been hypothesized to be positively correlated with sensitivity to drug reward (Hunt and Amit, 1987). Place conditioning procedures are frequently used to index the rewarding properties of selfadministered drugs as indicated by the acquisition of conditioned place preference (Carr et al., 1989; Tzschentke, 1998). Oral 
ethanol self-administration has long been regarded as an index of the rewarding efficacy of ethanol (Myers and Veal, 1972). We hypothesized that DARPP-32 mutant mice would display reduced sensitivity to the rewarding and aversive effects of ethanol, given that pharmacologically or molecularly induced reductions in dopamine function are associated with reductions in ethanol drinking (Dyr et al., 1993; Phillips et al., 1998), conditioned taste aversion (Risinger et al., 1999), ethanol-stimulated activity (Risinger et al., 1992a), and oral ethanol self-administration (Risinger et al., 2000).

\section{MATERIALS AND METHODS}

Animals. The present study used homozygous KO mice $(-/-)$ in comparison to homozygous wild-type $(\mathrm{WT})$ mice $(+/+)$. Male congenic mice on a C57BL/6J background (N10) were produced at The Rockefeller University (Fienberg et al., 1998). Animals were between 4 and 6 months old at the beginning of training. Naive mice were used for each experiment. Mice used in the taste conditioning study were housed individually in stainless-steel hanging cages $(14 \times 18 \times 18 \mathrm{~cm})$ with wire-mesh fronts and bottoms. Mice used in the place conditioning study were housed in groups of four in polycarbonate cages $(27.9 \times 9.5 \times 12.7 \mathrm{~cm})$ with cob bedding. Mice in the operant self-administration study were initially housed 2-4 per cage in polycarbonate cages. After training, mice in the operant self-administration study were housed in mouse operant chambers $23 \mathrm{hr} / \mathrm{d}$ (see procedure below). For all studies, a $12 \mathrm{hr}$ light/dark cycle was in effect (lights on at 7:00 A.M.), and the colony or testing rooms were maintained at an ambient temperature of $21 \pm 1^{\circ} \mathrm{C}$. The place conditioning and taste conditioning studies were conducted during the light cycle. For the ethanol self-administration study, lever response training was conducted during the light cycle. Lab chow was available ad libitum in the home cage. Animals in the taste conditioning and ethanol self-administration experiments had their access to fluids restricted as described herein.

Taste conditioning. The taste conditioning study was conducted in the home cages. Fluids were presented at room temperature in $25 \mathrm{ml}$ graduated glass cylinders fitted with stainless-steel drinking spouts inserted through the front of the cage. Consumption was measured to the nearest $0.1 \mathrm{ml}$ and was corrected for evaporation and spillage by subtracting the mean fluid loss measured in two drinking tubes placed on an empty cage for an equal amount of time. Mice of each genotype were randomly assigned to ethanol dose groups ( $n=5-8 /$ group). Subjects were adapted to a water restriction regimen ( $2 \mathrm{hr}$ of water per day from 9:00-11:00 A.M.) over a $6 \mathrm{~d}$ period. At $48 \mathrm{hr}$ intervals over the next $10 \mathrm{~d}$, mice had access to a $0.2 \mathrm{M} \mathrm{NaCl}$ solution between 9:00 and 10:00 A.M. We have found $\mathrm{NaCl}$ to be an effective flavor stimulus in inbred and SwissWebster mice using this design (Risinger and Cunningham, 1992, 1995; Risinger, 1997; Risinger et al., 1999). For the first four trials (conditioning), immediately after access to the $\mathrm{NaCl}$ solution, each mouse received 0,2 , or $4 \mathrm{gm} / \mathrm{kg}$ ethanol ( $20 \% \mathrm{v} / \mathrm{v}$, i.p.). On the final test (trial 5), subjects were given access to $\mathrm{NaCl}$, but did not receive ethanol. During conditioning, all mice also received $30 \mathrm{~min}$ access to tap water $5 \mathrm{hr}$ after each $\mathrm{NaCl}$ access period, to prevent dehydration. On intervening days, subjects had $2 \mathrm{hr}$ access to water (9:00-11:00 A.M.).

Place conditioning. The place conditioning apparatus consisted of eight identical acrylic and aluminum chambers $(30 \times 15 \times 15 \mathrm{~cm})$, each enclosed in a ventilated, light and sound-attenuating box (EN V-015M; MedAssociates, St. Albans, VT). Infrared light sources and detectors were positioned opposite each other at $5 \mathrm{~cm}$ intervals on the long walls of each chamber, $2.2 \mathrm{~cm}$ above the floor surface. Occlusion of the infrared light beams was used both as a measure of locomotor activity and to determine the animal's position in the chamber. Data were recorded each minute by computer. The floor of each box consisted of interchangeable halves with one of two distinctive textures: "hole" floors were made from perforated stainless steel with $6.4 \mathrm{~mm}$ round holes on $9.5 \mathrm{~mm}$ staggered centers; "grid" floors were composed of $2.3 \mathrm{~mm}$ stainless-steel rods mounted $6.4 \mathrm{~mm}$ apart in Plexiglas rails.

The place conditioning procedure was conducted daily Mondays through Fridays. The experimental sequence began with a 5 min habituation session, which was intended to reduce the novelty and stress associated with handling, injection, and exposure to the apparatus. All subjects received saline $(10 \mathrm{ml} / \mathrm{kg})$ and were immediately placed in the conditioning apparatus for 5 min on a smooth floor covered with paper.

For conditioning, KO mice $(n=24)$ and WT mice $(n=24)$ mice were randomly assigned to one of two conditioning subgroups ( $n=12$ ) subgroup) and exposed to an unbiased differential conditioning procedure. Conditioning was conducted using a between-group discrimination design (Cunningham, 1993), where conditioning trials consisted of pairings of a distinctive floor after ethanol exposure and pairings of a different floor with saline. Conditioning subgroups within each genotype were matched for exposure to ethanol and floor type and differed only in the specific floor-ethanol relationship (Cunningham, 1993). On alternate days mice received $2 \mathrm{gm} / \mathrm{kg}$ ethanol (CS + sessions) before placement on the grid floor (Grid+ subgroup) or the hole floor (Grid- subgroup). Mice received saline ( $\mathrm{CS}-$ sessions) before placement on the other floor type. Presentation of $\mathrm{CS}+$ and $\mathrm{CS}-$ sessions was counterbalanced for order of presentation. The $2 \mathrm{gm} / \mathrm{kg}$ ethanol dose was chosen because this dose produces reliable conditioned place preference in a variety of mouse genotypes (Risinger et al., 1994, 1996; Cunningham, 1995; Risinger and Oakes, 1996a). Eight conditioning sessions (four CS + , four $\mathrm{CS}-$ ) were given before the first preference test. Four additional conditioning sessions were performed before the second preference test, and an additional four conditioning sessions performed before a third and final preference test. For each preference test, all subjects received saline injections before placement in the apparatus for a $60 \mathrm{~min}$ session with half grid floor and half hole floor (left-right position counterbalanced within groups).

Operant ethanol self-administration. Lever response training was conducted with four mouse operant chambers (modular mouse test chamber, ENV-307A; MedAssociates) each equipped with one ultra sensitive mouse lever (ENV-310; MedAssociates), liquid dipper with a $0.02 \mathrm{ml}$ cup (ENV-303; MedAssociates), and $100 \mathrm{~mA}$ house light. The house light was located on the opposite wall from the location of the lever and liquid dipper and was on when a session was active. Each operant chamber was enclosed in a light-sound-attenuating cubicle (ENV-015M; MedAssociates). For $23 \mathrm{hr}$ sessions, 16 mouse operant chambers (ENV-003; MedAssociates) enclosed in light/sound attenuating cubicles were used. Each chamber was equipped with two ultra-sensitive mouse levers, liquid dipper with a $0.02 \mathrm{ml}$ cup, $20 \mathrm{mg}$ pellet dispenser (ENV-203-20; MedAssociates), drinking tube, and house light. The access well for the liquid dipper was located in the center of the right side panel. The access well for the pellet dispenser was located in the center of the left panel. The levers were placed on the left side of the liquid dipper well and pellet dispenser. The drinking tube $(25 \mathrm{ml}$ glass graduated cylinder fitted with a stainless steel drinking spout) was located in the center of the front panel and connected to a contact lickometer (ENV-250A; MedAssociates). The house light was centered on the left side panel $9.5 \mathrm{~cm}$ above the floor. Session parameters and data collection were controlled by computers adjacent to the chambers using MedAssociates interface modules.

During training, subjects received $2 \mathrm{hr}$ access to water each day, $4 \mathrm{hr}$ after training sessions. Subjects were first trained to lever press for $20 \%$ $\mathrm{w} / \mathrm{v}$ sucrose solution. Initially, one lever press resulted in $10 \mathrm{sec}$ access to the dipper cup [i.e., fixed ratio (FR) 1 schedule of reinforcement]. During the course of a $10 \mathrm{~d}$ training phase, the schedule of reinforcement was gradually increased to FR4, and the dipper access period was reduced to 5 sec. When training was complete, the subjects entered a $15 \mathrm{~d}$ initiation phase during which an increasing concentration of ethanol was gradually introduced to the sucrose solution. The concentration of sucrose was gradually reduced such that at the end of this phase subjects were receiving access to $10 \% \mathrm{v} / \mathrm{v}$ ethanol in tap water. Eight mice of each genotype began and completed lever response training and the initiation phase.

After the initiation phase, subjects $(n=8 \mathrm{KO}, 8 \mathrm{WT})$ were placed in operant chambers for $23 \mathrm{hr}$ sessions. Initially, $10 \% \mathrm{v} / \mathrm{v}$ ethanol was available from the dipper (FR4), food from the pellet dispenser (20 mg Noyes formula A pellets; FR1), and water from the drinking tube. Each day, subjects were removed from the chamber for $1 \mathrm{hr}$ to clean and resupply the chambers. A $12 \mathrm{hr}$ light/dark cycle was maintained throughout the procedure.

The first session was used for acclimation to the chambers and procedure, and data from this session were not subjected to analysis of genotype differences. In addition, malfunction of the pellet dispenser in one chamber required the removal of one KO mouse from the study. Subsequently, phase 1 consisted of 20 consecutive $23 \mathrm{hr}$ sessions with $10 \% \mathrm{v} / \mathrm{v}$ ethanol available. At the end of phase 1 , the concentration of ethanol was changed every four sessions (designated as phase 2). The following $\% \mathrm{v} / \mathrm{v}$ concentrations of ethanol were presented in the following order: $5,10,20,30$, and 0 . For phase $3,0.2 \% \mathrm{w} / \mathrm{v}$ saccharin was used 

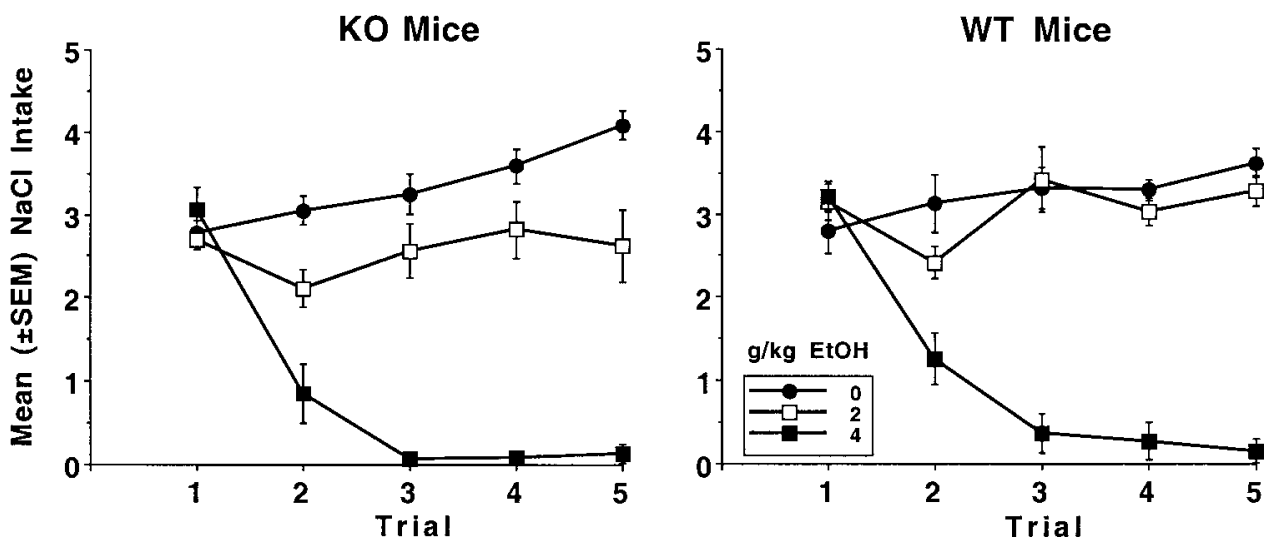

Figure 1. Mean $( \pm$ SEM) $\mathrm{NaCl}$ intakes (in milliliters) for DARPP-32 KO mice and WT mice during the taste-conditioning study. On trials $1-4$ (conditioning), after 60 min access to $0.2 \mathrm{M} \mathrm{NaCl}$, groups received either saline or ethanol $(2 \mathrm{gm} / \mathrm{kg}$ or $4 \mathrm{gm} /$ kg, i.p.). On trial 5 , groups received a final $60 \mathrm{~min}$ access period to $\mathrm{NaCl}$. Trials were conducted every $48 \mathrm{hr}$, and subjects received $2 \mathrm{hr}$ access to water between trials.

as the ethanol vehicle. The addition of $0.2 \%$ saccharin was expected to increase overall ethanol consumption in both strains (cf. Risinger et al., 1998). The $\% \mathrm{v} / \mathrm{v}$ concentration of ethanol was changed every four sessions in the following order: $0,5,10$, and 20 .

Statistical analysis. ANOVA was used for all initial comparisons. The alpha level for all analyses was set at 0.05 . For the floor preference tests in the place conditioning study, planned between-group comparisons examined conditioning subgroup for each genotype (Keppel, 1991). For the operant self-administration study, initial comparisons of genotype focused on daily session response rates for ethanol and food, and water intake. Further, a microanalysis of eating and drinking was conducted using a procedure that defined temporally related sequences of behavior as bouts (Samson et al., 1988). An ethanol bout consisted of four or more dipper presentations with $\leq 2 \mathrm{~min}$ between each dipper presentation. A food bout was defined as two or more pellet deliveries within $\leq 2 \mathrm{~min}$. A water bout consisted of at least 25 consecutive licks with $\leq 2$ min between each lick. The relationship between food intake and ethanol bouts was also determined (prandial bouts or nonprandial bouts). Prandial bouts occurred during or within 5 min of completion of a food bout. Nonprandial bouts occurred at least $5 \mathrm{~min}$ after the completion of a food bout.

\section{RESULTS}

\section{Acquisition of ethanol-induced conditioned taste aversion}

Figure 1 depicts mean $( \pm \mathrm{SEM}) \mathrm{NaCl}$ intakes for each genotype over the course of the five $\mathrm{NaCl}$ access periods. Ethanol produced dose-dependent reductions in $\mathrm{NaCl}$ intake over trials, indicating the development of conditioned taste aversion. Both knock-out and wild-type mice showed similar levels of conditioned aversion, suggesting no influence of genotype in sensitivity to the aversive effects of ethanol measured in this design. Genotype $\times$ ethanol dose $\times$ trial analysis showed significant effects of ethanol dose $\left(F_{(2,37)}=72.6 ; p<0.001\right)$, trial $\left(F_{(4,148)}=22.7 ; p<0.001\right)$, and ethanol dose $\times$ trial $\left(F_{(8,148)}=46.3 ; p<0.001\right)$. Effects of genotype, genotype $\times$ ethanol dose, genotype $\times$ trial, and genotype $\times$ ethanol dose $\times$ trial were nonsignificant (all $F$ values $<$ 1.5).

\section{Ethanol place preference conditioning}

Locomotor activity levels measured during the place conditioning procedure indicated that each genotype had similar levels of activity in the absence of drug treatment. However, KO mice showed greater sensitivity to ethanol-stimulated activity than WT mice. Activity during the habituation session (activity counts per minute: KO mice, $107.3 \pm 4.6$; WT mice, $109 \pm 5.1)$ was the same in both genotypes $\left(F_{(1,46)}=0.1 ; p<0.7\right)$. Mean $( \pm$ SEM $)$ activity counts per minute during conditioning are shown in Figure 2. For each CS + session, when subjects received $2 \mathrm{gm} / \mathrm{kg}$ ethanol, mean activity levels were higher than those seen on CS - sessions when subjects received saline. Genotype $\times$ session type $(\mathrm{CS}+/ \mathrm{CS}-)$
Locomotor Activity During Place Conditioning

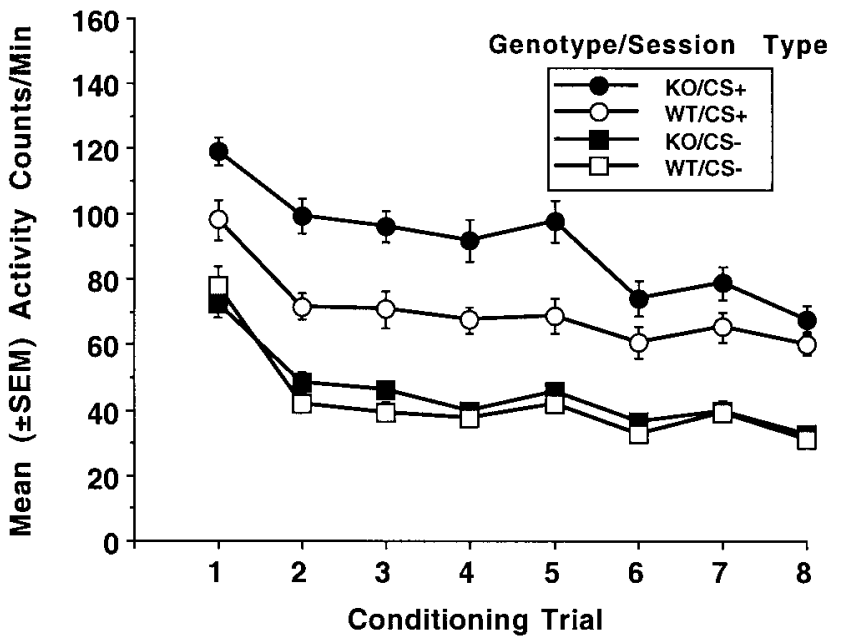

Figure 2. Mean ( \pm SEM) activity counts per minute for DARPP-32 KO mice and WT mice during place-conditioning trials. On CS + trials groups received ethanol $(2 \mathrm{gm} / \mathrm{kg}$, i.p. $)$. On CS + trials the same groups received saline. Immediately after injections, subjects were placed in the conditioning chambers for a $5 \mathrm{~min}$ trial. $\mathrm{CS}+/ \mathrm{CS}-$ trials were counterbalanced for order of presentation.

comparisons for each conditioning trial yielded significant effects of session type on each conditioning trial $\left(\right.$ all $F$ values $_{(1,46)}>45.4$; $p$ values $<0.001)$. Significant genotype $\times$ session type effects

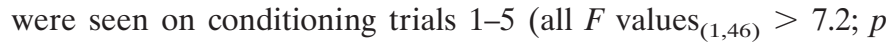
values $<0.01$ ), but not on conditioning trials $6-8$ (all $F$ values $\left._{(1,46)}<3.9 ; p<0.053\right)$. Comparisons of session type in each genotype separately yielded significant session type effects on all conditioning trials (all $F$ values $_{(1,23)}>5.3 ; p$ values $<0.03$ ). For $\mathrm{CS}+$ sessions, significant genotype effects were noted on condi-

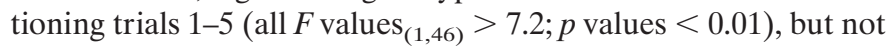

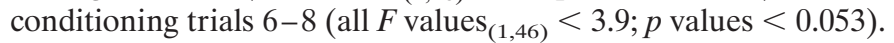
Genotype effects were not seen on any $\mathrm{CS}-$ session (all $F$ values $_{(1,46)}<2.8, p$ values $\left.<0.1\right)$. Overall, activity levels declined over the course of conditioning. Both genotypes showed reduced levels of activity under $\mathrm{CS}+$ and $\mathrm{CS}-$ conditions after conditioning trial 1, indicating habituation to the apparatus and procedure. Analysis of activity levels over CS - sessions yielded a significant effect of session $\left(F_{(7,322)}=68.3 ; p<0.001\right)$, but not genotype $\left(F_{(1,46)}=0.7 ; p<0.4\right)$ or genotype $\times \operatorname{session}\left(F_{(7,322)}=1.4 ; p<\right.$ $0.2)$. Analysis of activity levels over $\mathrm{CS}+$ sessions yielded significant effects of genotype $\left(F_{(1,46)}=14.0 ; p<0.001\right)$, session 


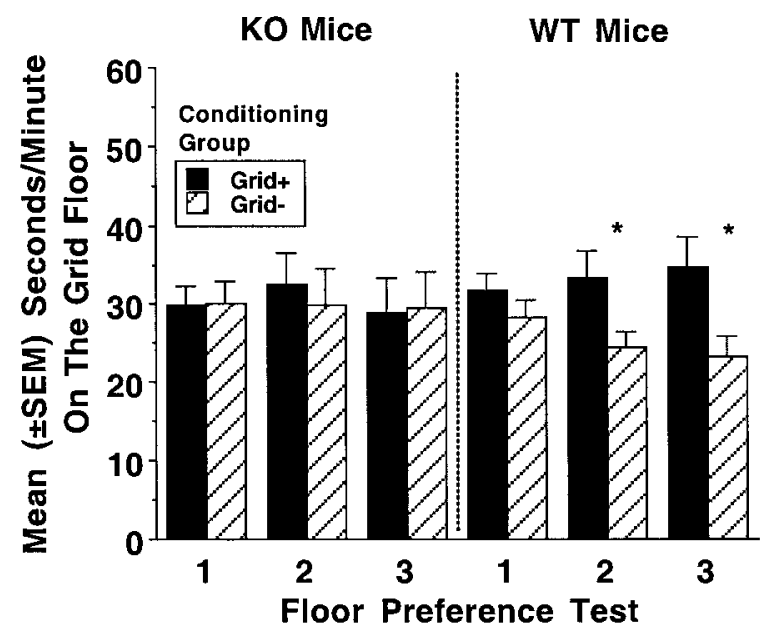

Figure 3. Mean $( \pm$ SEM) seconds per minute spent on the grid floor during floor choice testing for DARPP-32 KO mice and WT mice. Test 1 occurred after four conditioning trials, test 2 after two additional conditioning trials, and test 3 after two more additional conditioning trials. Grid+ groups had previously received pairings of the grid floor with drug treatment (and hole floor with saline), whereas Grid- groups had previously received pairings of the grid floor with saline (and hole floor with drug treatment). Conditioned place preference $\left({ }^{*} p<0.05\right)$ is shown when time spent on grid floor by the Grid + group exceeds time spent on the grid floor by the Grid- group.

$\left(F_{(7,322)}=29.7 ; p<0.001\right)$, and genotype $\times \operatorname{session}\left(F_{(7,322)}=\right.$ $2.3 ; p<0.04)$. As already indicated, the genotype $\times$ session interaction was caused by KO mice showing higher activity levels than WT mice on the first five sessions but not the last three sessions.

Mean $( \pm$ SEM) seconds per minute on the grid floor during the three separate preference tests are shown in Figure 3. The results of the first test (after four conditioning trials) are shown on the left, the results of the second test (after two additional conditioning trials) are shown in the center, and the results of the third test (after two more additional conditioning trials) are shown on the right. As indicated by the between-group comparison of the Grid + and Grid - conditioning groups, WT mice displayed conditioned preference for the ethanol-paired floor on the second and third tests. In contrast, $\mathrm{KO}$ mice did not show ethanolinduced conditioned place preference. Planned between-group comparisons in each genotype revealed significant effects of conditioning group in WT mice on test $2\left(F_{(1,22)}=4.6 ; p<0.04\right)$ and test $3\left(F_{(1,22)}=6.2 ; p<0.02\right)$ but not test $1\left(F_{(1,22)}=1.3 ; p<0.3\right)$.
KO mice did not show evidence of place conditioning on any test

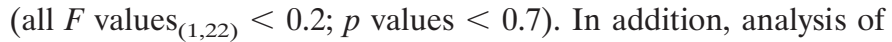
conditioning group over test sessions for the WT mice yielded significant effects of conditioning group $\left(F_{(1,22)}=4.5 ; p<0.05\right)$ and test $\times$ conditioning group $\left(F_{(2,44)}=5.9 ; p<0.005\right)$.

An alternative analysis of genotype differences in the preference tests used difference scores calculated for each subject of the total seconds spent on the ethanol-paired floor minus the seconds spent on the saline-paired floor. Mean $( \pm$ SEM) difference scores for the KO mice were $-2.2 \pm 218.4$ on test $1,15.5 \pm 392.4$ on test 2 , and $-36.4 \pm 383.1$ on test 3 . Mean $( \pm$ SEM) difference scores for the WT mice were $203.3 \pm 176.9$ on test $1,532 \pm 245.4$ on test 2 , and $686.5 \pm 270.7$ on test 3 . Although WT mice spent more time on the ethanol-paired floor compared to KO mice, significant genotype effects were not seen on any test (all $F$ val$\left.\operatorname{ues}_{(1,46)}<2.4 ; p<0.1\right)$.

\section{Operant ethanol self-administration}

Figures 4-6 depict ethanol level responding, food lever responding, and water intake for phases $1-3$, respectively. Table 1 gives ethanol bouts, water bouts, and food bouts for each phase. Each subject's data from phase 1 was averaged into four-session blocks. For phases 2 and 3, each subject's data was averaged over each ethanol concentration. During phase 1 , WT mice responded more overall on the ethanol lever than $\mathrm{KO}$ mice. Genotype $\times$ trial block analysis showed a significant effect of genotype $\left(F_{(1,13)}=4.7 ; p<0.05\right)$, but not trial block $\left(F_{(4,52)}=2.0 ; p<0.1\right)$ or genotype $\times$ trial block $\left(F_{(4,52)}=0.6 ; p<0.7\right)$. A similar analysis showed that food lever responding did not differ between $\mathrm{KO}$ and WT mice (genotype, $F_{(1,13)}=0.8 ; p<0.3$; trial block, $F_{(4,52)}=2.0 ; p<0.1$; genotype $\times$ trial block, $F_{(4,52)}=0.4 ; p<$ $0.8)$. Water intakes were similar for both genotypes and declined slightly over sessions. Analysis indicated a significant effect of trial block $\left(F_{(4,52)}=4.6 ; p<0.005\right)$, but not genotype $\left(F_{(1,13)}=1.2\right.$; $p<0.3)$ or genotype $\times$ trial block $\left(F_{(4,52)}=0.3 ; p<0.8\right)$. Both $\mathrm{KO}$ and WT mice displayed ethanol responding in the form of bouts, and ethanol bout frequency increased over the course of phase 1 (trial block: $F_{(4,52)}=4.1 ; p<0.03$ ). Although WT mice showed higher bout frequencies per session, this difference did not reach statistical significance (genotype: $F_{(1,13)}=3.9 ; p<$ $0.07)$. Analysis indicated that both KO and WT mice had overall similar frequencies of food lever bouts (genotype: $F_{(1,13)}=1.6$; $p<0.2)$. However, significant fluctuations in food bout frequency were noted (trial block, $F_{(4,52)}=7.9 ; p<0.001$; genotype $\times$ trial block, $\left.F_{(4,52)}=4.4 ; p<0.004\right)$. Follow-up analyses indicated WT mice had higher food bout frequencies compared to $\mathrm{KO}$ mice
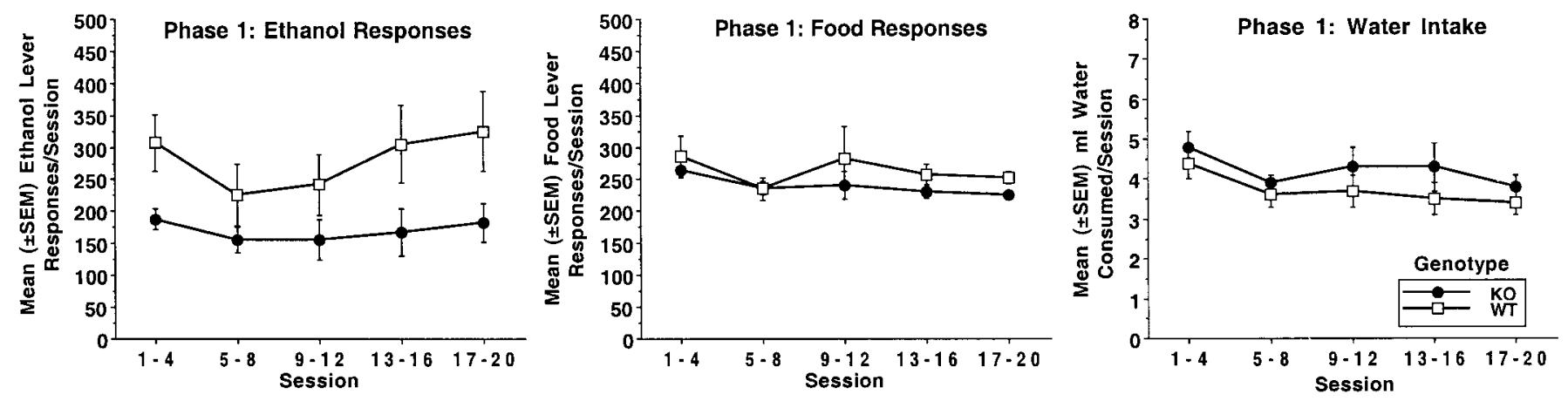

Figure 4. Mean ( \pm SEM) number of ethanol lever responses per $23 \mathrm{hr}$ session (left panel), food lever responses (middle panel), and milliliters of water intake (right panel) during phase 1 for DARPP-32 KO mice $(n=7)$ and WT mice $(n=8)$. Ethanol was presented on an FR4 schedule of reinforcement. Food was presented on an FR1 schedule of reinforcement. Each subject's data was averaged into four session blocks. 

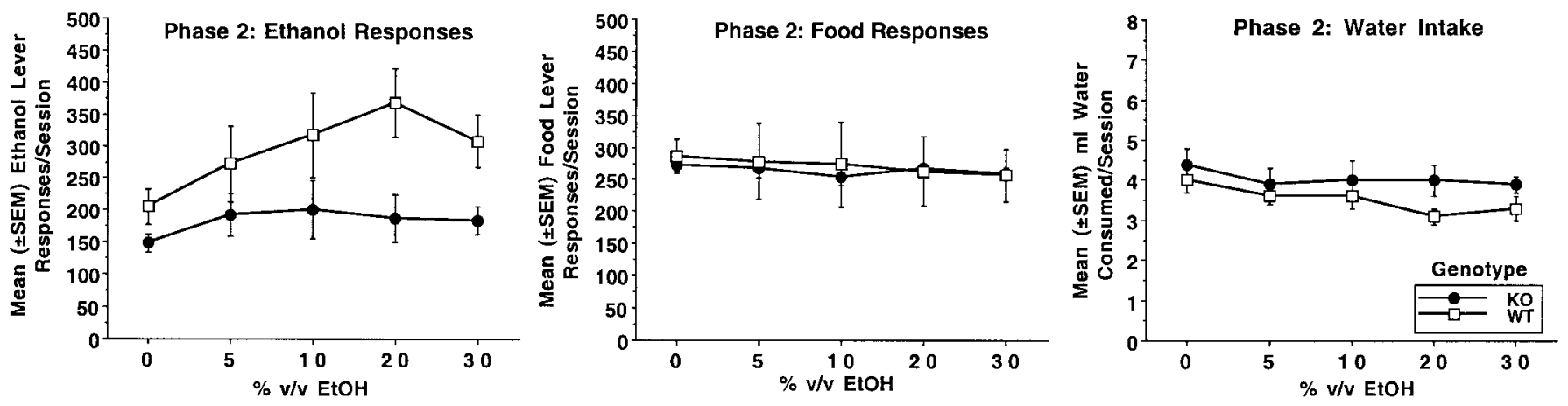

Figure 5. Mean ( \pm SEM) number of ethanol lever responses per session (left panel), food lever responses (middle panel), and milliliters of water intake (right panel) during phase 2 for DARPP-32 KO mice $(n=7)$ and WT mice $(n=8)$. Ethanol was presented on an FR4 schedule of reinforcement. Food was presented on an FR1 schedule of reinforcement. Subjects were presented with each ethanol concentration (\% v/v) for four consecutive $23 \mathrm{hr}$ sessions.

during the last trial block $\left(F_{(1,13)}=10.9 ; p<0.006\right)$. Analysis of water bout frequency showed no significant effect of genotype $\left(F_{(1,13)}=0.7 ; p<0.4\right)$, trial block $\left(F_{(4,52)}=2.3 ; p<0.09\right)$, or genotype $\times$ trial block $\left(F_{(4,52)}=0.4 ; p<0.7\right)$.

During phase 2, WT continued to show higher levels of responding on the ethanol level compared to $\mathrm{KO}$ mice at certain ethanol concentrations. Overall genotype $\times$ ethanol concentration analysis yielded significant effects of genotype $\left(F_{(1,13)}=4.7\right.$; $p<0.05)$ and ethanol concentration $\left(F_{(4,52)}=3.7 ; p<0.01\right)$. Further analyses at each ethanol concentration indicated WT mice responded more on the ethanol lever than $\mathrm{KO}$ mice at the 20 and $30 \%$ concentrations (both $F$ values $_{(1,13)}>6.5$; $p$ values $<$ 0.02 ), but not at the 0,5 , or $10 \%$ concentrations (all $F$ val$\operatorname{ues}_{(1,13)}<3.2$; $p$ values $\left.<0.08\right)$. WT mice showed concentrationdependent changes in responding $\left(F_{(4,28)}=3.2 ; p<0.03\right)$, whereas KO mice did not $\left(F_{(4,24)}=1.2 ; p<0.3\right)$. Paired $t$ comparisons indicated responding in WT mice was greater for 20 and $30 \%$ ethanol than for plain water $(t$ values(7) $>3.5 ; p$ values $<0.01)$. Food lever responding was the same in both $\mathrm{KO}$ and WT mice and did not change when ethanol concentration was altered (Genotype: $F_{(1,13)}=0.1, p<0.7$; ethanol concentration: $F_{(4,52)}=2.0, p<0.1$; genotype $\times$ ethanol concentration, $F_{(4,52)}=$ $0.9, p<0.5)$. Water intakes were the same in both genotypes $\left(F_{(1,13)}=2.1 ; p<0.1\right)$. WT mice showed a higher frequency of ethanol lever bouts compared to $\mathrm{KO}$ mice with analysis yielding a significant effect of genotype $\left(F_{(1,13)}=4.6 ; p<0.05\right)$ and ethanol concentration $\left(F_{(4,52)}=3.5 ; p<0.01\right)$. WT mice had higher numbers of food bouts compared to $\mathrm{KO}$ mice. Analysis yielded a significant effect of genotype $\left(F_{(1,13)}=8.5 ; p<0.01\right)$ but not ethanol concentration $\left(F_{(4,52)}=0.5 ; p<0.7\right)$ or genotype $\times$ ethanol concentration $\left(F_{(4,52)}=0.4 ; p<0.8\right)$. Both KO and WT mice had similar frequencies of water bouts during phase 2 (Genotype: $F_{(1,13)}=0.04 ; p<0.8$ ).

The addition of saccharin in phase 3 increased overall responding in both genotypes. Compared to KO mice, WT mice showed higher response rates on the ethanol lever overall, even when ethanol was not present (i.e., $0.2 \%$ saccharin alone). Overall analysis yielded a significant effect of genotype $\left(F_{(1,13)}=5.4 ; p<\right.$ $0.04)$ and ethanol concentration $\left(F_{(3,39)}=5.6 ; p<0.003\right)$. Although analysis of ethanol concentration in WT mice indicated concen-

tration-dependent changes in responding $\left(F_{(3,21)}=3.6 ; p<0.03\right)$, follow-up paired $t$ comparisons indicated no significant differences across concentrations ( $t$ values $<1.9$; $p$ values $<0.1$ ). However, KO mice showed significant changes in responding across ethanol concentration $\left(F_{(3,18)}=6.8 ; p<0.003\right)$. Specifically, response rates were higher for $5 \%$ ethanol $\left(T_{(6)}=2.9 ; p<\right.$ $0.03)$ and $10 \%$ ethanol $\left(T_{(6)}=4.0 ; p<0.007\right)$ compared to response rates for saccharin alone. $\mathrm{KO}$ and $\mathrm{WT}$ mice did not differ in food lever responding $\left(F_{(1,13)}=0.1 ; p<0.8\right)$, although food lever responding decreased with the addition of ethanol $\left(F_{(3,39)}=24.6 ; p<0.001\right)$. KO mice consumed more water than WT mice (Genotype: $F_{(1,13)}=5.2 ; p<0.04$ ). Analysis also yielded a significant effect of ethanol concentration $\left(F_{(3,39)}=\right.$ 22.7; $p<0.001)$ and genotype $\times$ ethanol concentration $\left(F_{(3,39)}=\right.$ $4.1 ; p<0.01)$. Follow-up analyses indicated both WT and KO
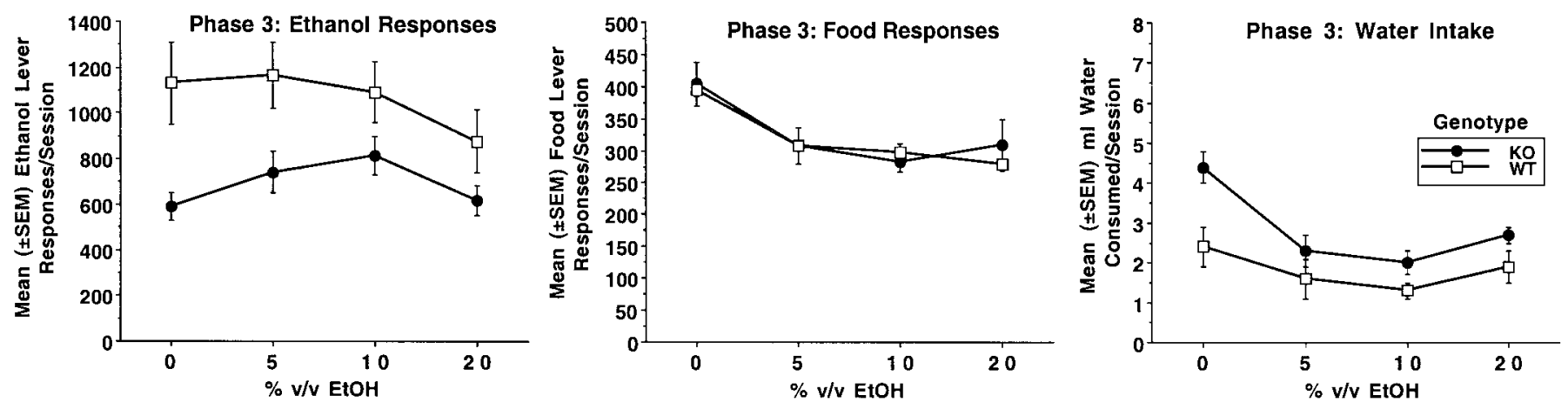

Figure 6. Mean ( \pm SEM) number of ethanol lever responses per session (left panel), food lever responses (middle panel), and milliliters of water intake (right panel) during phase 3 for DARPP-32 KO mice $(n=7)$ and WT mice $(n=8)$. Ethanol was presented on an FR4 schedule of reinforcement. Food was presented on an FR1 schedule of reinforcement. Subjects were presented with each ethanol concentration (\% v/v) for four consecutive $23 \mathrm{hr}$ sessions. 
Table 1. Mean ( \pm SEM) number of ethanol bouts, number of water bouts, and number of food bouts during phases 1-3

\begin{tabular}{llllll} 
& \multicolumn{1}{l}{ Session } \\
\cline { 2 - 6 } Genotype & $1-4$ & $5-8$ & $9-12$ & $13-16$ & $17-20$ \\
\hline Phase 1 & & & & & \\
Ethanol bouts & & & & & \\
$\quad$ KO & $2.0(0.4)$ & $2.2(0.7)$ & $2.3(0.8)$ & $3.4(1.2)$ & $3.9(1.1)$ \\
WT & $4.1(0.9)$ & $4.1(1.3)$ & $5.0(1.5)$ & $7.4(1.9)$ & $8.0(2.1)$ \\
Food bouts & & & & & \\
$\quad$ KO & $52.6(2.8)$ & $43.0(1.8)$ & $45.2(1.6)$ & $45.3(1.9)$ & $42.9(1.3)$ \\
WT & $50.3(1.6)$ & $48.1(1.5)$ & $43.9(1.9)$ & $49.0(1.6)$ & $50.0(1.5)$ \\
Water bouts & & & & & \\
KO & $41.2(2.7)$ & $34.0(2.2)$ & $35.5(3.2)$ & $35.7(4.4)$ & $34.9(3.6)$ \\
WT & $36.1(2.1)$ & $33.7(1.5)$ & $33.7(3.5)$ & $33.3(2.7)$ & $31.0(2.8)$ \\
\hline & Ethanol (\% v/v) & & & \\
\cline { 2 - 6 } & 0 & 5 & 10 & 20 & 30 \\
\hline
\end{tabular}

Phase 2

Ethanol bouts

KO $\quad 2.4(0.5) \quad 3.8(1.1) \quad 4.1(1.4) \quad 3.3(1.0) \quad 3.8(0.7)$

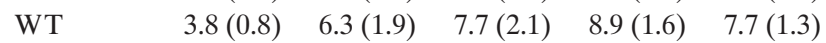

Food bouts

KO $\quad 43.8(2.9) \quad 43.2(1.7) \quad 43.8(2.2) \quad 43.5(2.5) \quad 43.4(1.0)$

$\begin{array}{llllll}\text { WT } & 51.7(2.2) & 51.8(1.9) & 51.5(2.7) & 50.5(1.6) & 49.0(1.9)\end{array}$

Water bouts

$\begin{array}{llllll}\text { KO } & 37.3(4.1) & 34.1(3.8) & 33.5(4.7) & 35.2(3.5) & 35.5(2.2)\end{array}$

$\begin{array}{llllll}\text { WT } & 40.2(3.0) & 33.7(2.4) & 32.8(3.1) & 30.0(2.8) & 35.2(2.3)\end{array}$

\begin{tabular}{lrll}
\hline \multicolumn{2}{l}{ Ethanol $(\% \mathrm{v} / \mathrm{v})$} & \\
\cline { 2 - 4 } & 5 & 10 & 20 \\
\hline
\end{tabular}

Phase 3

Ethanol bouts

$\begin{array}{lllll}\text { KO } & 15.4(1.8) & 20.1(2.0) & 19.9(1.5) & 15.5(1.6) \\ \text { WT } & 27.1(4.1) & 31.8(3.8) & 30.2(4.4) & 24.0(3.9) \\ \begin{array}{l}\text { Food bouts } \\ \quad\end{array} & 57.3(1.8) & 46.8(2.2) & 44.7(2.6) & 42.0(1.9) \\ \text { KO } & 62.3(2.2) & 55.0(1.1) & 53.8(1.6) & 53.2(2.2) \\ \text { WT } & & & & \\ \text { Water bouts } & 34.3(3.8) & 18.6(3.2) & 16.9(2.6) & 20.7(2.8) \\ \text { KO } & 20.7(4.5) & 12.2(2.7) & 10.4(2.6) & 18.1(3.9) \\ \text { WT } & & & & \end{array}$

mice had significant declines in water intake over ethanol concentration (KO mice: $F_{(3,18)}=24.9 ; p<0.001$; WT mice: $\left.F_{(3,21)}=4.1 ; p<0.02\right)$. KO mice drank more water compared to WT mice at the $0 \%$ ethanol concentration $\left(F_{(1,13)}=10.9 ; p<\right.$ 0.006 ) but not at the 5, 10, or $20 \%$ concentrations (all $F$ values $\left._{(1,13)}<4.0 ; p<0.06\right)$. The number of ethanol lever bouts was increased in both genotypes compared to levels seen without saccharin (i.e., phase 1 and 2). However WT mice showed higher ethanol bout frequencies than $\mathrm{KO}$ mice with analysis yielding a significant effect of genotype $\left(F_{(1,13)}=6.3 ; p<0.03\right)$ and ethanol concentration $\left(F_{(3,39)}=6.6 ; p<0.001\right)$. WT mice also had higher food bout frequencies compared to $\mathrm{KO}$ mice $\left(F_{(1,13)}=19.2 ; p<\right.$ $0.001)$. KO mice showed higher numbers of water bouts with the analysis yielding a significant genotype $\times$ ethanol concentration interaction $\left(F_{(3,39)}=30.6 ; p<0.001\right)$. Both genotypes showed significant effects of ethanol concentration $\left(\mathrm{KO}: F_{(3,18)}=42.9\right.$;
Table 2. Mean ( \pm SEM) grams per kilogram ethanol presented per session during each experimental phase

\begin{tabular}{lrr} 
& \multicolumn{2}{l}{ Mean gm/kg ethanol per session } \\
\cline { 2 - 3 } Experimental phase & KO & WT \\
\hline Phase 1 & & \\
Trials & $2.4(0.2)$ & $4.0(0.6)$ \\
$1-4$ & $2.0(0.2)$ & $3.1(0.7)$ \\
$5-8$ & $2.0(0.4)$ & $3.3(0.7)$ \\
$9-12$ & $2.2(0.5)$ & $4.0(0.7)$ \\
$13-16$ & $2.4(0.4)$ & $4.3(0.8)$ \\
$17-20$ & & \\
Phase 2 & & $1.8(0.4)$ \\
Ethanol $(\% \mathrm{v} / \mathrm{v})$ & $1.2(0.2)$ & $4.1(0.8)$ \\
5 & $2.6(0.6)$ & $9.9(1.3)$ \\
10 & $4.8(1.0)$ & $12.1(1.8)$ \\
20 & $6.8(0.7)$ & \\
30 & & $7.4(1.0)$ \\
Phase 3 & & $13.8(1.5)$ \\
Ethanol $(\% \mathrm{v} / \mathrm{v})$ & $4.5(0.6)$ & $22.4(3.8)$ \\
5 & $9.8(1.1)$ & \\
10 & $15.1(1.7)$ & \\
20 & & \\
\hline
\end{tabular}

Table 3. Mean $( \pm$ SEM) number of dippers per fluid-lever bout during each experimental phase

\begin{tabular}{lll} 
Experimental phase & KO & WT \\
\hline Phase 1 & & \\
Trials & & \\
$1-4$ & $5.4(0.4)$ & $5.7(0.3)$ \\
$5-8$ & $5.1(0.5)$ & $5.4(0.3)$ \\
$9-12$ & $5.0(0.3)$ & $5.4(0.5)$ \\
$13-16$ & $5.4(0.3)$ & $5.6(0.4)$ \\
$17-20$ & $5.3(0.3)$ & $5.9(0.3)$ \\
Phase 2 & & \\
Ethanol $(\% \mathrm{v} / \mathrm{v})$ & & $5.3(0.2)$ \\
0 & $5.5(0.4)$ & $5.1(0.3)$ \\
5 & $5.2(0.4)$ & $5.5(0.3)$ \\
10 & $6.2(0.6)$ & $6.7(0.5)$ \\
20 & $5.7(0.6)$ & $6.7(0.3)$ \\
30 & $5.8(0.4)$ & \\
Phase 3 & & $7.3(0.5)$ \\
Ethanol $(\% \mathrm{v} / \mathrm{v})$ & & $7.4(0.7)$ \\
0 & $6.7(0.5)$ & $7.4(0.7)$ \\
5 & $7.3(0.6)$ & $7.1(0.7)$ \\
10 & $8.1(1.0)$ &
\end{tabular}

$p<0.001$; WT: $\left.F_{(3,21)}=7.3 ; p<0.002\right)$. Significant genotype effects were only seen at the $0 \%$ concentration $\left(F_{(1,13)}=5.2 ; p<\right.$ $0.04)$.

Table 2 gives mean $( \pm$ SEM) gram per kilogram ethanol intakes based on the number of dippers presented during a session. As would be expected based on ethanol response rates, WT mice had higher gram per kilogram ethanol doses per session than KO mice during each experimental phase. A significant genotype effect was noted in phase $1\left(F_{(1,13)}=5.4 ; p<0.04\right)$, but no effect of trial 
Table 4. Mean ( \pm SEM) number of prandial and nonprandial fluid lever bouts during each experimental phase

\begin{tabular}{|c|c|c|c|c|}
\hline \multirow[b]{2}{*}{ Experimental phase } & \multicolumn{2}{|l|}{ Prandial } & \multicolumn{2}{|c|}{ Nonprandial } \\
\hline & $\mathrm{KO}$ & WT & $\mathrm{KO}$ & WT \\
\hline \multicolumn{5}{|l|}{ Phase 1} \\
\hline \multicolumn{5}{|l|}{ Trials } \\
\hline $1-4$ & $1.2(0.2)$ & $1.8(0.3)$ & $1.1(0.2)$ & $2.6(0.7)$ \\
\hline $5-8$ & $1.0(0.4)$ & $2.3(0.7)$ & $1.1(0.4)$ & $1.8(0.7)$ \\
\hline $9-12$ & $1.3(0.4)$ & $2.6(0.7)$ & $1.1(0.6)$ & $2.4(0.9)$ \\
\hline $13-16$ & $2.1(0.7)$ & $3.9(0.7)$ & $1.4(0.7)$ & $3.5(1.4)$ \\
\hline $17-20$ & $2.3(0.7)$ & $4.5(1.1)$ & $1.6(0.6)$ & $3.5(1.2)$ \\
\hline \multicolumn{5}{|l|}{ Phase 2} \\
\hline \multicolumn{5}{|l|}{ Ethanol $(\% \mathrm{v} / \mathrm{v})$} \\
\hline 0 & $1.5(0.3)$ & $2.6(0.6)$ & $0.9(0.4)$ & $1.2(0.3)$ \\
\hline 5 & $2.3(0.6)$ & $3.7(1.1)$ & $1.5(0.7)$ & $2.5(0.8)$ \\
\hline 10 & $2.4(0.7)$ & $4.2(1.0)$ & $1.8(0.8)$ & $3.4(1.2)$ \\
\hline 20 & $2.2(0.6)$ & $6.0(1.0)$ & $1.1(0.5)$ & $3.6(0.8)$ \\
\hline 30 & $2.7(0.5)$ & $4.7(0.6)$ & $1.1(0.4)$ & $3.0(0.8)$ \\
\hline \multicolumn{5}{|l|}{ Phase 3} \\
\hline \multicolumn{5}{|l|}{ Ethanol $(\% \mathrm{v} / \mathrm{v})$} \\
\hline 0 & $14.1(4.1)$ & $13.9(2.2)$ & $6.3(0.8)$ & $14.4(3.2)$ \\
\hline 5 & $11.3(1.0)$ & $16.2(1.9)$ & $8.8(1.2)$ & $15.7(2.1)$ \\
\hline 10 & $11.4(0.9)$ & $14.8(2.1)$ & $8.5(0.8)$ & $15.6(2.5)$ \\
\hline 20 & $9.6(1.3)$ & $13.4(1.6)$ & $5.9(1.2)$ & $10.3(2.4)$ \\
\hline
\end{tabular}

block or genotype $\times$ trial block (both $F$ values $_{(4,52)}<1.7$; $p<$ 0.1 ). Analysis of phase 2 doses yielded a significant effect of genotype $\left(F\right.$ values $\left._{(1,13)}=7.8 ; p<0.02\right)$, ethanol concentration $\left(F_{(3,39)}=42.4 ; p<0.001\right)$, and genotype $\times$ ethanol concentration $\left(F_{(3,39)}=4.7 ; p<0.007\right)$. Both genotypes showed significant increases in ethanol dose with increasing ethanol concentration $\left(\mathrm{KO}\right.$ mice: $F_{(3,18)}=28.9 ; p<0.001$; WT mice: $F_{(3,21)}=25.2 ; p<$ $0.001)$. Significant genotype effects were seen at the $20 \%$ concentration $\left(F_{(1,13)}=8.5 ; p<0.01\right)$ and the $30 \%$ concentration $\left(F_{(1,13)}=6.3 ; p<0.03\right)$. During phase 3 , overall analysis yielded a significant effect of ethanol concentration $\left(F_{(2,26)}=50.9 ; p<\right.$ $0.001)$ but not genotype $\left(F_{(1,13)}=3.8 ; p<0.07\right)$ or genotype $\times$ ethanol concentration $\left(F_{(2,26)}=1.7 ; p<0.2\right)$.

Table 3 gives mean ( \pm SEM) ethanol bout size for each phase for both genotypes. No effects of genotype were seen in analyses of each phase (all $F$ values $_{(1,13)}<2.4$; $p$ values, 0.1 ). Bout size remained constant over trial block during phase $1\left(F_{(4,52)}=0.7\right.$; $p<0.6)$ and over ethanol concentration during phase $3\left(F_{(3,39)}=\right.$ $1.2 ; p<0.3)$ with no interactions of genotype with trial block in phase $1\left(F_{(4,52)}=0.1 ; p<1.0\right)$ or ethanol concentration in phase $3\left(F_{(3,39)}=1.2 ; p<0.3\right)$. However, analysis of phase 2 ethanol bout size yielded significant effects of ethanol concentration $\left(F_{(4,52)}=5.0 ; p<0.002\right)$ and genotype $\times$ ethanol concentration $\left(F_{(4,52)}=2.6 ; p<0.05\right)$. Follow-up analyses indicated ethanol bout size in KO mice did not differ from WT mice at any ethanol

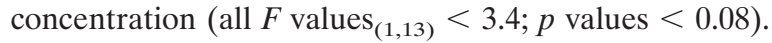

Table 4 gives mean $( \pm \mathrm{SEM})$ number of prandial and nonprandial bouts for each genotype during each phase. Each genotype generated both types of bouts, of which prandial bouts constituted $\sim 50-60 \%$ of the total number. During phase 1 , the frequency of prandial bouts increased over trials $\left(F_{(4,52)}=5.5\right.$; $p<0.001)$. Also, WT mice showed higher frequencies of prandial bouts compared to KO mice $\left(F_{(1,13)}=4.6 ; p<0.05\right)$. Nonprandial bout frequency remained constant $\left(F_{(4,52)}=1.3 ; p<0.3\right)$ and was similar in both genotypes $\left(F_{(1,13)}=2.6 ; p<0.1\right)$. Prandial bouts also increased during phase $2\left(F_{(4,52)}=4.6 ; p<0.003\right)$ with WT mice showing higher prandial bout frequencies than $\mathrm{KO}$ mice $\left(F_{(1,13)}=5.1 ; p<0.04\right)$. As in phase 1 , nonprandial bout frequency remained stable in phase $2\left(F_{(4,52)}=2.3 ; p<0.07\right)$, and $\mathrm{KO}$ mice and WT mice had similar nonprandial bout frequencies $\left(F_{(1,13)}=3.5 ; p<0.08\right)$. The frequency of each bout type was higher in phase 3 for both genotypes. Prandial bout frequency was similar for KO and WT mice $\left(F_{(1,13)}=1.4 ; p<0.3\right)$ and remained stable over ethanol concentration $\left(F_{(3,39)}=0.7 ; p<0.5\right)$. However, nonprandial bout frequency was higher in WT mice compared to $\mathrm{KO}$ mice $\left(F_{(1,13)}=6.1 ; p<0.03\right)$. Also, nonprandial bout frequency deceased over ethanol concentration $\left(F_{(3,39)}=\right.$ $7.4 ; p<0.001)$.

\section{DISCUSSION}

DARPP-32 KO mice self-administered less ethanol than WT mice across a variety of conditions, indicating a decrement in oral ethanol reinforcement. However, DARPP-32 KO mice and WT mice did not differ in the acquisition of ethanol-induced conditioned taste aversion, suggesting that sensitivity to the aversive effects of ethanol were equivalent. DARPP-32 KO mice showed enhanced sensitivity to ethanol-stimulated activity, indicating the $\mathrm{KO}$ mice do not have a general lack of response to ethanol. However, mice lacking DARPP-32 failed to acquire ethanolinduced conditioned place preference. Overall, these findings indicate DARPP-32 is an important component for sensitivity to ethanol reinforcement but not ethanol aversion.

Pairing a distinctive flavor with subsequent ethanol exposure generally results in a conditioned aversion to the flavor (Sherman et al., 1988). In the present study, both KO and WT mice displayed similar levels of conditioned taste aversion, showing that elimination of DARPP-32 had no influence on the aversive effects of ethanol measured in this design. However, pharmacological studies have indicated dopaminergic systems contribute to ethanol aversion. Specifically, dopamine D2 receptor blockade reduces the acquisition of ethanol-induced conditioned taste aversion (Sklar and Amit, 1977; Risinger et al., 1999). Dopamine D1 receptor or D4 receptor blockade only marginally reduce ethanol-conditioned taste aversion (Risinger et al., 1999; Thrasher et al., 1999). The present results do not show a positive relationship between ethanol reinforcement and sensitivity to ethanol-conditioned taste aversion. Furthermore, the present results are not consistent with the notion of dopaminergic mediation of ethanol aversion. However, ethanol appears to produce aversion by two mechanisms (Hunt and Amit, 1987). One mechanism is central in origin and resembles the mechanism of other reinforcing drugs. A second emetic mechanism relies on the accumulation of acetaldehyde (Aragon et al., 1991). Thus, the doses of ethanol used in the present study may have produced conditioned taste aversion by peripheral mechanisms in which central changes in dopaminergic systems would not be expected to be influential. For example, dopamine D2 receptor blockade does not prevent conditioned taste aversion produced by the emetic agent lithium chloride (Hunt et al., 1985). It should also be noted that reductions in $\mathrm{NaCl}$ intake may be related to conditioned behavioral changes other than those directly related to aversive motivational effects. For example, conditioned activation in the presence of the ethanol-associated flavor could have interfered with consumption.

In place conditioning using various mouse strains, pairing distinctive environmental cues with ethanol exposure results in subsequent conditioned place preference (Cunningham et al., 1992; 
Risinger et al., 1994; Risinger and Oakes, 1996a). Place conditioning procedures have been used for examination of neuropharmacological mechanisms related to ethanol reward (Risinger et al., 1992a,b, 1996; Risinger and Oakes, 1996b; Thrasher et al., 1999). Neither dopaminergic nor opioid mechanisms, using pharmacological agents, have been implicated in the acquisition of ethanolinduced conditioned place preference (Risinger et al., 1992a; Cunningham et al., 1995; Thrasher et al., 1999). However, specific serotonergic receptor mechanisms appear particularly important for the acquisition of this task (Risinger and Oakes, 1996b; Risinger et al., 1996) as well as GABAergic receptor mechanisms (Chester and Cunningham, 1999a; although see Chester and Cunningham, 1999b; Risinger et al., 1992b). The results of the present study suggest a role for DARPP-32 in mediating ethanol reward. Specifically, lack of DARPP-32 is associated with lowered sensitivity to the rewarding effects of ethanol as illustrated by the failure of $\mathrm{KO}$ mice to acquire ethanol-induced conditioned place preference. However, the present results should be viewed with some caution. Although the comparisons of conditioning subgroup in the WT mice are consistent with the acquisition of conditioned preference, the overall magnitude of preference was modest compared to that seen in other mouse strains examined in a similar multiple conditioning-testing procedure (Risinger et al., 1996; Risinger and Oakes 1996a). This, in part, is likely attributable to the C57BL/6 background. Although C57BL/6 mice acquire place preference to ethanol paired cues (Kelly et al., 1997; Nocjar et al., 1999), this strain shows lower magnitudes of conditioned preference compared to other inbred mouse strains (e.g., DBA/2J; Cunningham et al., 1992). The lack of conditioning in KO mice and the modest conditioning noted in WT mice could be interpreted as attributable to a reduction in learning ability. However, results from the tasteconditioning study indicate KO and WT mice are able to learn Pavlovian associations. Furthermore, DARPP-32 KO mice are able to learn a food-reinforced operant task (Heyser et al., 2000). Thus, the place conditioning results are not likely attributable to a nonspecific learning decrement or general insensitivity to the motivational effects of ethanol.

In mice, ethanol produces locomotor stimulation at doses $\leq 2$ gm/kg (Risinger and Oakes, 1996a). Moreover, a positive relationship between ethanol-induced locomotor stimulation and ethanol reward has been proposed (Wise and Bozarth, 1987), and ethanolstimulated activity is thought to reflect the rewarding euphoric effects of ethanol (Phillips and Shen, 1996). During conditioning, a $2 \mathrm{gm} / \mathrm{kg}$ ethanol dose produced locomotor stimulation, a response seen in a number of other mouse strains, including C57BL/6 (Cunningham, 1995). KO mice showed higher levels of activity after ethanol compared to WT mice. Both genotypes showed similar levels of activity after saline. Therefore, the notion of a positive relationship between ethanol-stimulated activity and ethanol reward was not supported, given that KO mice showed ethanol-induced stimulation of activity but not conditioned place preference. Dissociation of ethanol-stimulated activity and acquisition of ethanol-induced conditioned place preference has also been noted in studies using pharmacological manipulations. For example, haloperidol eliminates the locomotor stimulant effects of ethanol without influencing the magnitude of conditioned preference in a design similar to that used here (Risinger et al., 1992a). However, it has been noted that the relationship between ethanolstimulated activity and the acquisition of ethanol-induced conditioned place preference depends on a variety of factors including gender, locomotor activity levels after initial exposure to ethanol or saline, and changes over multiple place conditioning trials in sen- sitivity to ethanol-stimulated activity (Nocjar et al., 1999). Thus, conclusions about differences in sensitivity to ethanol-stimulated activity and ethanol-conditioned place preference noted in the present genotypes await additional studies (e.g., ethanol dose manipulations).

The present study characterized oral ethanol self-administration using a relatively long-term procedure, with results indicating DARPP-32 exerts a modulating influence on ethanol-reinforced behavior. Responding for food and water intakes were similar in both genotypes. However, $\mathrm{KO}$ mice responded less on the ethanolassociated lever across a variety of ethanol-concentration conditions compared to WT mice. As expected, access to unsweetened oral ethanol was an effective reinforcing stimulus in WT mice with C57BL/6 lineage (cf. Risinger et al., 1998). For example, during phase 2, WT mice showed ethanol concentration-dependent responding, indicating ethanol is an effective reinforcer in this genotype. KO mice did not show concentration-dependent changes in responding for unsweetened ethanol. Although overall ethanol responding was reduced under all conditions in $\mathrm{KO}$ mice compared to WT mice, KO mice showed increases in ethanol-lever responding when ethanol was added to a saccharin solution. KO mice also responded less for plain saccharin. Thus, KO mice display reductions in responding for more than one reinforcer, which is consistent with the notion of a general role for dopaminergic systems in reward processes (Wise et al., 1978) or in the production of instrumental responding (Salamone et al., 1997). WT mice generated a bout pattern of responding for ethanol similar to that seen in C57BL/6 mice. KO mice also produced ethanol bouts, although at lower levels than those seen in WT mice. Bout size remained relatively constant in both genotypes, with differences in ethanol intake determined by the number of bouts rather than bout size. Similar patterns have been noted in C57BL/6 mice (Risinger et al., 1998) and ethanol preferring $P$ rats (Files et al., 1993). In addition, both genotypes showed prandial and nonprandial bouts. Higher ethanol intakes seen in WT mice compared to KO mice were based on greater frequencies of food-related drinking (i.e., prandial bouts) when ethanol was presented unsweetened. However, with sweetened ethanol available, higher ethanol intakes in WT mice were based on an increase in nonprandial drinking.

In summary, DARPP-32 KO mice showed specific decrements in ethanol reinforcement, but not in ethanol aversion. Food and water consumption were not altered in the KO mice. In contrast to the reduced sensitivity to ethanol reinforcement, DARPP-32 KO mice showed heightened sensitivity to ethanol-stimulated activity, but did not acquire ethanol-induced conditioned place preference. These results are generally consistent with pharmacological studies supporting a role for dopamine D1 and D2 receptor systems in the control of ethanol intake (Pfeffer and Samson, 1988; Dyr et al., 1993). Furthermore, mice lacking dopamine D1 receptors or dopamine D2 receptors consume less ethanol (El-Ghundi et al., 1998; Phillips et al., 1998). However, dopamine D2 receptor KO mice display a pronounced reduction in operant responding for a variety of reinforcers, including ethanol (Risinger et al., 2000). Dopamine system involvement in the production of ethanol-induced conditioned place preference appears less clear in studies showing that dopamine D2 and D4 receptor antagonists do not influence the acquisition of this response (Risinger et al., 1992a; Thrasher et al., 1999). However, DARPP-32 appears particularly important in the regulation of dopamine D1 receptor function (Fienberg et al., 1998). Results from D1 receptor-specific manipulations have not been reported, which may be an important mechanism for the production of ethanol conditioned place preference. Failure to 
note differences between $\mathrm{KO}$ and WT mice in ethanol-conditioned taste aversion is also consistent with a primary role for D1 mechanisms, because a D1 receptor antagonist was only marginally effective in reducing ethanol conditioned taste aversion compared to a D2 receptor antagonist (Risinger et al., 1999). Overall, the present results suggest DARPP-32 is an important modulator of ethanol-seeking behavior.

\section{REFERENCES}

Aragon CMG, Abitol M, Amit Z (1991) Ethanol-induced CTA mediated by acetaldehyde through central catecholamine activity. Psychopharmacology 103:74-77.

Carr GD, Fibiger HC, Phillips AG (1989) Conditioned place preference as a measure of drug reward. In: Neuropharmacological basis of reward (Liebman JM, Cooper SJ, eds) pp 264-319. New York: Oxford UP.

Chester JA, Cunningham CL (1999a) GABA(A) receptors modulate ethanol-induced conditioned place preference and taste aversion in mice. Psychopharmacology 144:363-372.

Chester JA, Cunningham CL (1999b) Baclofen alters ethanol-stimulated activity but not conditioned place preference or taste aversion in mice. Pharmacol Biochem Behav 63:325-331.

Civelli O, Bunzow JR, Grandy DK (1993) Molecular diversity of the dopamine receptors. Annu Rev Pharmacol Toxicol 32:281-307.

Cunningham CL (1993) Pavlovian drug conditioning. In: Methods in behavioral pharmacology (van Haaren F, ed), pp 349-381. New York: Elsevier.

Cunningham CL (1995) Localization of genes influencing ethanolinduced conditioned place preference and locomotor activity in BXD recombinant inbred mice. Psychopharmacology 120:28-41.

Cunningham CL, Neihus DR, Malott DH, Prather LK (1992) Genetic differences in the rewarding and activating effects of morphine and ethanol. Psychopharmacology 107:385-393.

Cunningham CL, Dickinson SD, Okorn DM (1995) Naloxone facilitates extinction but does not affect acquisition or expression of ethanolinduced conditioned place preference. Exp Clin Psychopharmacol 3:330-343.

Dyr W, McBride WJ, Lumeng L, Li TK, Murphy JM (1993) Effects of $\mathrm{D} 1$ and $\mathrm{D} 2$ receptor agents on ethanol consumption in the high-alcoholdrinking (HAD) line of rats. Alcohol 10:207-212.

El-Ghundi M, George SR, Drago J, Fletcher PJ, Fan T, Nguyen T, Liu C, Sibley DR, Westphal H, O'Dowd BF (1998) Disruption of dopamine D1 receptor gene expression attenuates alcohol-seeking behavior. Eur J Pharmacol 353:149-158.

Fienberg AA, Greengard P (2000) The DARPP-32 knockout mouse. Brain Res Rev 31:313-319.

Fienberg AA, Hiroi N, Mermelstein PG, Song W-J, Snyder GL, Nishi A, Cheramy A, O'Callaghan JP, Miller DB, Cole DG, Corbett R, Haile CN, Cooper DC, Onn SP, Grace AA, Ouimet CC, White FJ, Hyman SE, Surmeier DJ, Girault J-A, Nestler EJ, Greengard P (1998) DARPP-32: regulator of the efficacy of dopaminergic neurotransmission. Science 281:838-842.

Files FJ, Andrews CM, Lewis RS, Samson HH (1993) Effects of ethanol concentration and fixed ratio requirement on ethanol selfadministration by $\mathrm{P}$ rats in a continuous access situation. Alcohol Clin Exp Res 17:61-68.

Greengard P, Nairn A, Girault J-A, Ouimet CC, Snyder G, Fisone G, Allen P, Fienberg A, Nishi A (1998) The DARPP-32/protein phosphatase-1 cascade: a model for signal integration. Brain Res Rev 26:274-284.

Greengard P, Allen PB, Nairn AC (1999) Beyond the dopamine receptor: the DARPP-32/protein phosphatase-1 cascade. Neuron 23:435-447.

Heyser CJ, Fienberg AA, Greengard P, Gold LH (2000) DARPP-32 knockout mice exhibit impaired reversal learning in a discriminated operant task. Brain Res 867:122-130.

Hunt T, Amit Z (1987) Conditioned taste aversion induced by selfadministered drugs: paradox revisited. Neurosci Biobehav Rev 11:107-130.

Hunt T, Switzman L, Amit Z (1985) Involvement of dopamine in the aversive stimulus properties of cocaine in rats. Pharmacol Biochem Behav 22:945-948

Kelly BM, Bandy AL, Middaugh LD (1997) A study examining intravenous ethanol-conditioned place preference in $\mathrm{C} 57 \mathrm{BL} / 6 \mathrm{~J}$ mice. Alcohol Clin Exp Res 21:1661-1666.

Keppel G (1991) Design and analysis: a researchers handbook. Englewood Cliffs, NJ: Prentice Hall.

Koob GF (1992) Drugs of abuse: anatomy, pharmacology and function of reward pathways. Trends Pharmacol Sci 13:177-184.

Koob GF (1999) The role of the striatopallidal and extended amygdala in drug addiction. Ann NY Acad Sci 877:445-460.

Koob GF, Roberts AJ, Schulteis G, Parsons LH, Heyser CJ, Hyytia P, Merlo-Pich E, Weiss F (1998) Neurocircuitry targets in ethanol reward and dependence. Alcohol Clin Exp Res 22:3-9.
Myers RD, Veal WL (1972) The determinants of alcohol preference in animals. In: The pathogenesis of alcoholism (Kissin B, Begleiter $\mathrm{H}$, eds), pp 131-168. New York: Plenum.

Nocjar C, Middaugh LD, Tavernetti M (1999) Ethanol consumption and place-preference conditioning in the alcohol-preferring C57BL/6 mouse: relationship with motor activity patterns. Alcohol Clin Exp Res 23:683-692.

Pfeffer AO, Samson HH (1988) Haloperidol and apomorphine effects on ethanol reinforcement in free feeding rats. Pharmacol Biochem Behav 29:343-350.

Phillips TJ, Shen EH (1996) Neurochemical bases of locomotion and ethanol stimulant effects. Int Rev Neurobiol 39:243-282.

Phillips TJ, Brown KJ, Burkhart-Kasch S, Wenger CD, Kelly MA, Rubinstein M, Grandy DK, Low MJ (1998) Alcohol preference and sensitivity are markedly reduced in mice lacking dopamine D2 receptors. Nat Neurosci 1:610-615.

Risinger FO (1997) Fluoxetine's effects on ethanol's rewarding, aversive and stimulus properties. Life Sci 61:235-242.

Risinger FO, Cunningham CL (1992) Genetic differences in ethanolinduced hyperglycemia and conditioned taste aversion. Life Sci 50:113-118.

Risinger FO, Cunningham CL (1995) Genetic differences in ethanolinduced conditioned taste aversion after ethanol preexposure: Alcohol $12: 535-539$

Risinger FO, Oakes RA (1996a) Dose- and conditioning trial-dependent ethanol-induced conditioned place preference in Swiss-Webster mice. Pharmacol Biochem Behavior 55:117-123.

Risinger FO, Oakes RA (1996b) Mianserin enhancement of ethanolinduced conditioned place preference. Behav Pharmacol 7:294-298.

Risinger FO, Dickinson SD, Cunningham CL (1992a) Haloperidol reduces ethanol-induced motor activity stimulation but not conditioned place preference. Psychopharmacology 107:453-456.

Risinger FO, Malott DH, Riley AL, Cunningham CL (1992b) Effect of Ro 15-4513 on ethanol-induced conditioned place preference. Pharmacol Biochem Behav 43:97-102.

Risinger FO, Malott DH, Prather LK, Niehus DR, Cunningham CL (1994) Motivational properties of ethanol in mice selectively bred for ethanol-induced locomotor differences. Psychopharmacology 116:207-216.

Risinger FO, Bormann NM, Oakes RA (1996) Reduced sensitivity to ethanol reward, but not ethanol aversion in mice lacking 5-HT1b receptors. Alcohol Clin Exp Res 20:1401-1405.

Risinger FO, Brown MM, Doan AM, Oakes RA (1998) Mouse strain differences in oral operant ethanol reinforcement under continuous access conditions. Alcohol Clin Exp Res 22:677-684.

Risinger FO, Brown MM, Oakes RA, Love JA (1999) Effects of haloperidol or SCH-23390 on ethanol-induced conditioned taste aversion. Alcohol 18:139-145.

Risinger FO, Freeman PA, Rubinstein M, Low MJ, Grandy DK (2000) Lack of oral ethanol self-administration in dopamine D2 receptor knockout mice. Psychopharmacology, in press.

Salamone JD, Cousins MS, Snyder BJ (1997) Behavioral functions of nucleus accumbens dopamine: empirical and conceptual problems with the anhedonia hypothesis. Neurosci Biobehav Rev 21:341-359.

Samson HH, Tolliver GA, Pfeffer AD, Sadeghi K, Haraguchi M (1988) Relation of ethanol self administration to feeding and drinking in a nonrestricted access situation in rats initiated to self-administer ethanol using the sucrose-fading technique. Alcohol 5:375-385.

Sherman JE, Jorenby DE, Baker TB (1988) Classical conditioning with alcohol: acquired preferences and aversions, tolerance, and urges/craving. In: Theories on alcoholism (Chaudron CD, Wilkinson DA, eds) pp 173-237. Toronto: Addiction Research Foundation.

Sklar LS, Amit Z (1977) Manipulations of catecholamine systems block the conditioned taste aversion induced by self-administered drugs. Neuropharmacology 16:649-655.

Svenningsson P, Fienberg AA, Allen PB, Le Moine C, Lindskog M, Fisone G, Greengard P, Fredholm BB (2000) Dopamine D1 receptorinduced gene transcription is modulated by DARPP-32. J Neurochem 75:248-257.

Tabakoff B, Hoffman PL (1988) A neurobiological theory of alcoholism. In: Theories on alcoholism (Chaudron CD, Wilkinson DA, eds) pp 29-72. Toronto: Addiction Research Foundation.

Thrasher MJ, Freeman PA, Risinger FO (1999) Clozapine's effects on ethanol's motivational properties. Alcohol Clin Exp Res 23:1377-1385.

Tzschentke TM (1998) Measuring reward with the conditioned place preference paradigm: a comprehensive review of drug effects, recent progress and new issues. Prog Neurobiol 56:613-672.

Wise RA (1998) Drug-activation of brain reward pathways. Drug Alcohol Depend 51:13-22

Wise RA, Bozarth MA (1987) A psychomotor stimulant theory of addiction. Psychol Rev 94:469-492.

Wise RA, Spindler J, deWit H, Gerberg GJ (1978) Neuroleptic-induced "anhedonia" in rats: pimozide blocks reward quality of food. Science 201:262-264. 